\title{
Malee (Ashamed) Philosophy is a Defense Against Teenage Premarital Intimacy
}

\author{
Ernita Dewi ${ }^{1}$, Munawiah Munawiah ${ }^{2}$, Said Amirul Kamar ${ }^{3}$, Intan Wirantika Putri ${ }^{4}$ \\ \{ernita.dewi@ar-raniry.ac.id ${ }^{1}$,munawiah@ar-raniry.ac.id², said.amirulkamar@ar-raniry.ac.id ${ }^{3}$, \\ intanwirantika@gmail.com ${ }^{4}$ \}
}

UIN Ar-Raniry Banda Aceh, Indonesia

\begin{abstract}
Malee (ashamed) is a demeanor that refuses to do something when in contradiction with the local value of religion and local wisdom in the Aceh's lives today. The demeanor of Malee is shown when it comes to a man who is not they husband or they family. This behavior was instilled early in the parents of Aceh, for girls not so easily open a relationship with a man or anyone who wants to get close or got a desire for a despicable. For instance, as a girl, it would be a shame to welcome a male guest at home or to travel with a man somewhere quiet. This tenet is still deeply embedded in the lives of the Acehnese society. However, recently as social media influences and the spread of content leads to pornography, and also a chance for children and teenagers to get access to cell phones and the internet, the case of prenuptial relations more increase. Aceh has a philosophy of malee and running the law of syariat Islam affected by this free of life phenomenon. For that reason, this research is done to found the factor of dimming the shame that children and teenagers are less likely to be affected by the free life and valueless.
\end{abstract}

Keywords: Malee (ashamed); Gender; Manner

\section{Introduction}

The development of information technology that is very widespread today has led to changes in people's behavior, and a shift in moral values to be more bad and worrisome. One of them is the increasing number of cases of premarital sex that occur among teenagers. Many ways have been made so that moral values can still be maintained in society, especially the things that have engaged with religion and tradition. One of them is a norm that is a pearl of local wisdom in society. In Aceh, one of the local wisdom that has been highly preserved is held high of Malee (ashamed) demeanor in society. Malee (ashamed) is a demeanor that refuses to do something when in contradiction with Islamic law and also social norms.

Malee also shown when someone socializes with another person that does not has the relation of a brother or mahram (that would not be married), because of this behavior can lead to premarital sex. In Aceh society, the relationship between men and women is very strict, because it is feared that it will have an impact on promiscuity so that from the beginning this relationship has been in such a way as to be detained. One would be that if a male guest came to the house with a teenage girl, the community would monitor, even the parents would prohibit the presence of such guests if it was very important only to have them sit outside. It is strictly forbidden to visit at night. However, these days the condition has changed, some teenagers openly invite male guests to the house, even parents tend to support this activity. 


\section{Result and Discussion}

\subsection{Definition of Malee (ashamed) in Aceh Society}

Malee is a word from Aceh or In Indonesian as an ashamed. Malee is often referred to as ayeep, keunong malee, teuka malee, meunalee. Malee can translate as a demeanor that (1) not feeling well (despicable, lowly, and so on, because of doing something that is not good (not right, different from habit, having a disability or deficiency, etc.): for example, out of shame someone is caught stealing money; I'm embarrassed to meet guests because I haven't showered; (2) disinclined to do something because there is respect, a bit afraid; (3) less happy (lowly and so on), he feels ashamed to be in the midst of that important person.

In addition to the term of malee, Acehnese is also familiar with the words seugan (disinclined) and teumakout (fear). Seugan is usually used for things that are reluctant to do something because they respect the person. In the Indonesian dictionary, reluctant can be interpreted in several senses such as (1) lazy (doing something); disinclined; unwilling; do not want to; dislikes: those who are ashamed to ask will go astray on the way; those who are ashamed to work will have a hard life; (2) feel embarrassed (fear, and respect) to all students are embarrassed by the teacher. So according to some of the terms discussed above, malee is actually in Acehnese culture, it can also be in the form of teumakoet behavior. Malee or which is meant in this research is malee not doing or doing something because the behavior is contrary to religious values or values that apply in society, especially in the educational environment. With the malee's character, they become good human beings at school and in society.

According to Nabbani, an Aceh Culturalist, in Aceh society, manners in daily life are engaged with the traditional law. For instance, a girl has to comply with the law. If it is violated there will be risks, both social risks, and risks from Aceh's local customs. Examples of social risks such as getting gossip among the community, and examples of risks from local customs such as being ostracized and even expelled from their place of domicile. Aceh has rules that bind its people so they don't act outside the rules that have been set, therefore people, especially teenagers, rarely engage in promiscuity such as pre-marital intercourse because of the rules and a sense of malee in Aceh society.

Sanusi, an employee at the Aceh Traditional Council, malee is an identity. Malee of teenagers in Aceh Besar is still extant if they have pre-marital relations unless they do that outside the area where they live because of the strict control of the local community. Malee is accompanied by fear because of Allah's prohibition and responsibility.

\subsection{The Relationship between Culture of Ashamed and Islam}

In the local wisdom of Acehnese, malee is not a foreign term and is quite encountered in various activities, The malee generally stems from Islamic commands and thus becomes oral traditions of which are not directly known, can come from a great variety of religious (Quran and hadiths), traditions and cultural meaning of various peoples and cultures.

Ashamed culture is a top priority in society So that persons engaging in intimate acts out of wedlock are punished both religiously and mores. Researchers remember when a researcher's grandmother was alive in the 1990s, she maintained a good distance from any indication of adultery. One of the women who already had children lived in the research village, her husband had gone to Malaysia because of his involvement with Aceh Merdeka, which at that time had 
not yet reconciled with the Indonesian government. The news that developed was that Mrs. Y had been found committing adultery with a man that immigrant to the research village. Hearing that news, the community of the researcher's village began to be sympathetic to Mrs. Y. One day, when Mrs. Y asked something and came to the researcher's house. At that time, the researcher's grandmother welcoming Mrs. Y, but does not allowed Mrs. Y to come in and just stand outside the door, grandma will take what Mrs. Y asked for. After taking something that Mrs.Y asked, grandmother immediately closed the door. At that time, the researcher saw the incident, then asked the grandmother, why was Mrs.Y not allowed to come in and stand outside the door of the house. Grandma said, that someone who has committed adultery, then that person is dirty in body and soul, so they are no longer allowed to enter other people's homes.

Although local wisdom in Aceh is quite pervasive in all aspects of life, Nowadays, it has begun to fade, because these values are no longer integrated into teenagers' understanding of promiscuity. As a result of this concern, several policies have been issued by the government to maintain the existence of these values in the next generation. Malee is a foundation for morals, it is necessary to understand malee from an early age because malee is part of the faith, then developing malee values is included in the effort to increase faith and increase piety to Allah SWT, so that it has implications in all his actions, feeling good with the function of malee values in the various hadiths that have been mentioned. Lack of malee then lost one part of one's faith.

Hasbi Amiruddin also explicitly stated, Islamic education is an activity to develop all aspects of the human personality, and according to the hadith lasts a lifetime, on the other hand, education is an effort to strengthen faith. Aceh's customs have never been separated from Islamic teachings, in other words, Aceh's customary rules were adopted from the teachings of Islam. Before qanun khalwat, Aceh had managed to rule against a young couple in solitude. For instance, In ancient times there was a term in the Aceh Besar language, namely peunganjong which means male and female companions who marry to connect the two parties because of the malee nature of the bride. But now, there are no more penganjong or companions from each party because the bride and groom already know each other so they don't need a penganjong.

The feeling of malee has something to do with the Shari'a, if it doesn't have anything to do with the Shari'a it is said to be lust or it is called malee which is wrong. If examined in terminology the term malee is "Iman Malee Akal Ilmee". The highest degree of shame is malee to Allah while the lowest is malee to humans. Malee in the Shari'a are behaviors that are prohibited by religion. But now that term is rarely found. With a sense of shame, behavior in the form of prohibitions will not be carried out by teenagers.

\subsection{Malee's Digital Technology and Globalization Issues Against Teenagers' Tendencies in Pre-Marriage Intimate Relationships}

To maintain malee in teenagers, it is necessary to have the role of family, environment, and education, such as providing an understanding of the rules and the necessity of being ashamed. " If the feeling of malee is still attached to the soul of the teenager, it will fortify or minimize which leads to promiscuity'.

However, but for now, with the development of digital technology and the issue of globalization, the tendency of youth to pre-marriage intimacy is stronger. It has begun to be seen the difference between malee in ancient times and now, In the past, the way to convey feelings between men and women was by correspondence, but for now not anymore. The difference between ancient teenagers and now, 'In the past, if you just read a letter from a lover, you were ecstatic even though you didn't meet your lover. But right now, convey through digital or social 
media already used to see and more ecstatic when you can see for each other', According to Nabhani, there needs to be an effort to regenerate the shaming behavior, that is:

1. Engenders confidence that malee will keep us out of people's judgment

2. Socialization

3. Collaborate

4. Strict the surveillance

5. Education

According to Chairul Azman specify in Aceh there is also pre-marital intimate relationships exist but are rarely the case, some married because they had premarital intercourse, and some married because their parents thought they were ready or their parents are a teungku/ ustadz (teacher). The marriage limit in Aceh is 19 for women and 20 for men. One of the causes of premarital intercourse is the determination of the age requirement for marriage in Aceh. In Aceh Besar, there are villages, some of which are still strict in the rules of teenagers association, because in that village there are Islamic boarding schools so that teenagers have basic religious knowledge. There are also villages with a lack of religious knowledge that makes the teenagers become very free.

Widespread of teenagers association, today which has led to promiscuity, Chairul Azman admit right now, teenagers association are distorted when compared to the lives of teenagers in the past and now. One of the great influences is digital technology. Too many teenagers are using smartphones that simply cannot be unleashed from adult content.

The phenomenon of the high number of premarital sexual relations, where the Acehnese public was shocked by media reports about the arrest of three pairs of teenagers, including minors who were caught having sex parties. It was even more distressing than the child had some intimate relations. Not only promiscuous problems that distressed, but the incidence of child sexual abuse is also increasing in 2020. These realities have shaken societies today that are accustomed to living in a religious situation, especially regions with special autonomy that practice Islamic law. The Covid-19 pandemic has brought significant changes to the lifestyle of teenagers. The use of internet media and the freedom of children to use cell phones are allegedly triggering the tendency of teenagers to commit obscene acts such as promiscuity between men and women, in rural and urban areas. Aceh has the power of community control based on the indigenous character, it is called pageu gampong, in addition to the important role of both parents. The membership of the pageu gampong consists of the village chair (keuchik), the village secretary, the hamlet head, religious leaders, and members of the tuha peut or commonly referred to as village level DPRD members. This power can provide tight control so that the movement of youth activities that lead to violations of Islamic Shari'a or immoral acts, both in the field of promiscuity, drugs, and other crimes can be monitored as early as possible.

This is local wisdom in Aceh called Pageu Gampong (Village Fence). The presence of village officials is very much needed, especially in this era, where people are increasingly influenced by the free life that is triggered by the presence of the internet. Khalid, one of the village chairs in Aceh Besar District, also stated that the current condition of the community is different from the previous community. In the era of information disclosure and the development of communication technology, society has experienced many changes in mindset. They have their own opinion and the biggest influence of digital communication media is very strong. Access to pornographic content is a driving factor for the emergence of various sexual violence against women and children, as well as promiscuity between boys and girls.

During the Covid-19 pandemic, Nasrul Miadi admitted that many cases were reported by residents to the Aceh Civil Service and Wilayatul Hisbah Police Units (Satpol PP and WH). One of the cases reported and secured by residents is the case of an intimate relationship between 
a man and a 14 years old girl. In addition to the intimate relationship, drug cases were also found, where the couple used shabu-shabu (metamfetamina). This case was reported by residents because residents were distressed about the couple's behavior. It had been almost a few nights, the couple had been living in an empty shophouse. Every night the men bring underage teenagers to the place and they have premarital sex. The community became angry and arrested the 349 couples and then reported them to the Satpol PP and WH Aceh offices to be processed according to the applicable law. The role of village officials is very much needed so that all crimes and violations of Islamic law can be tackled. The community and gampong officials are very close to the cases that occurred.

Interviews conducted with one of the Satpol PP and WH Aceh staff stated that currently there are a lot of public reports about immoral or lewd acts committed by underage teenagers. When examined, the teenagers said that their promiscuity was influenced by social media and vulgar videos. And also, the lack of attention from families, especially parents to children, which in the end makes children feel like they are alienated, and look for other lives, by gathering with friends, without any more limits, in the end, there is an illicit relationship that is highly opposed.

\section{Conclusion}

Malee became the most important fortress to suppress the rampant promiscuity among teenagers. Malee must be instilled in children from an early age, becoming a character that is reflected in his life. With the malee in mind, a teenager will feel very uncomfortable hanging out freely with men who are not her mahram. Moreover in today's era, where access to the virtual world which is full of information about negative things is easily accessible. Only by cultivating a sense of shame, teenagers more or less get defense from the tendency to have premarital sex.

\section{Reference}

[1] Anonim, Kamus Aceh-Indonesia 2. (Jakarta: Pusat Pembinaan dan Pengembangan Bahasa. Depdibud, 1985)

[2] Anonim. Kamus Umum Bahasa Indonesia. (Jakarta : Pusat Pembinaan dan Pengembangan Bahasa Depdibud, Jakarta 1985) diunduh pada tanggal 25 Agustus 2021 http://kamusbahasaindonesia.org

[3] Anonim, Kamus Aceh - Indonesia 2. Pusat Pembinaan dan Pengembangan Bahasa (Jakarta: Depdibud 1985).

[4] Anonim, Kamus Umum Bahasa Indonesia, (Jakarta: Pusat Pembinaan dan Pengembangan Bahasa Depdibud, 1985) diunduh pada tanggal 25 Agustus 2021 http://kamusbahasaindonesia.org

[5] Anonim, Ensiklopedia Pengetahuan Al-Quran dan Hadist, dilengkapi dengan Asbabun Nuzul, Asbabul Wurud dan Penjelasannya, (Jakarta: Penerbit Kamil Pustaka, 2013).

[6] Al-Ustadz Yazid bin Abdul Qadir Jawas, Jika Tidak Malu Berbuat Sesuka Mu, https://www.alquran-sunnah.com/artikel/kategori/hadits/837-jika-engkau-tidak-malu,berbuatlah-sesukamu.html. diunduh tanggal 25 Agustus 2021.

[7] Anisa Ulfa Damayanti, 5-9 Juta anak Indonesia adalah Pecandu Narkoba, Oke Zonenews.https://news.okezone.com/read/2018/03/06/337/1868702/5-9-juta-anakindonesiajadi-pecandu-narkoba, diunduh Tanggal 26 Agustus 2021. 
[8] Anonim, Ensiklopedia Pengetahuan Al-Quran dan Hadist, dilengkapi dengan Asbabun Nuzul, Asbabul Wurud dan Penjelasannya, (Jakarta: Penerbit Kamil Pustaka., 2013).

[9] Badruzzaman Isamail, Ketua Majelis Adat Aceh (MAA) Provinsi Aceh, Wawancara Tanggal 13 Juni 2017

[10] Beth. B. Hess, Dkk. Sociology. Second Edition. (New York:Macmillan Publishing, 1985)

[11] Ernita Dewi dan Said Amirul Kamar. "The Role Of Community Characters in Sending Cases of Sexual Violence against Children". Konfrontasi Journal. 2020.

[12] Hasbi Amiruddin. Politik dan Pendidikan, (Banda Aceh: Cetakan Pertama, Penerbit ArRaniry Press. 2014).

[13] Kitab Hadist, Ibnu Majah, online, dapat diakses https://tafsirq.com/hadits/ibnu-majah/, Hadist Nomor 57, diunduh tanggal 20 Mei 2019

[14] Kitab Hadist Imam Malik, Online, https://tafsirq.com/hadits/malik/1406, Hadist Nomor 1406, diunduh tanggal 25 Agustus 2021

[15] Kitab Hadist Imam Malik, Online, https://tafsirq.com/hadits/malik/1406, Hadist Nomor 1406, diunduh tanggal 25 Agustus 2021

[16] Kitab Hadist Bukhari, Online, https://tafsirq.com/hadits/bukhari/5652, Hadist Nomor 5652, Diunduh Tanggal 25 Agustus 2021.

[17] Kitab Hadist Muslim, Online, https://tafsirq.com/hadits/muslim, Hadist Nomor 51, Diunduh Tanggal 26 Agustus 2021.

[18] Mijaz Iskandar, 2017. Pengajian Rutin Tafsir Minggu Malam, Mesjid Albadar, Tanggal 12 November 2017.

[19] Interview with Nabhani, Cultural and Historian Aceh On August 26, 2021

[20] Policy Analysis Interview, customary observer, gampong and mukim strengthening practitioners, Banda Aceh, Sanusi M. Syarif, On August 27, 2021

[21] Interview with the Chair of the Head of Religious Affairs, Aceh Besar, Chairul Azman, On August 30, 2021

[22] Yulsafli. Director of the Aceh Cultural Institute. Interview on 19 September 2017. 